\title{
Langmuir
}

pubs.acs.org/Langmuir

(C) 2010 American Chemical Society

\section{Origin of Lyotropic Liquid Crystalline Mesophase Formation and Liquid Crystalline to Mesostructured Solid Transformation in the Metal Nitrate Salt-Surfactant Systems}

\author{
Cemal Albayrak, ${ }^{\dagger}$ Necati Özkan, ${ }^{*}$ and Ömer Dag* ${ }^{\dagger}$ \\ ${ }^{\dagger}$ Department of Chemistry, Bilkent University, 06800 Ankara, Turkey, and ${ }^{\ddagger}$ Middle East Technical University, \\ Central Laboratories, 06531 Ankara, Turkey
}

Received September 7, 2010. Revised Manuscript Received September 17, 2010

\begin{abstract}
The zinc nitrate salt acts as a solvent in the $\mathrm{ZnX}-\mathrm{C}_{12} \mathrm{EO}_{10}\left(\mathrm{ZnX}\right.$ is $\left[\mathrm{Zn}\left(\mathrm{H}_{2} \mathrm{O}\right)_{6}\right]\left(\mathrm{NO}_{3}\right)_{2}$ and $\mathrm{C}_{12} \mathrm{EO}_{10}$ is $\mathrm{C}_{12} \mathrm{H}_{25^{-}}$ $\left.\left(\mathrm{OCH}_{2} \mathrm{CH}_{2}\right)_{10} \mathrm{OH}\right)$ lyotropic liquid crystalline (LLC) mesophase with a drastic dropping on the melting point of $\mathrm{ZnX}$. The salt-surfactant LLC mesophase is stable down to $-52{ }^{\circ} \mathrm{C}$ and undergoes a phase change into a solid mesostructured salt upon cooling below $-52{ }^{\circ} \mathrm{C}$; no phase separation is observed down to $-190{ }^{\circ} \mathrm{C}$. The $\mathrm{ZnX}-\mathrm{C}_{12} \mathrm{EO}_{10}$ mesophase displays a usual phase behavior with an increasing concentration of the solvent $(\mathrm{ZnX})$ in the media with an order of bicontinuous cubic $\left(\mathrm{V}_{1}\right)-2 \mathrm{D}$ hexagonal $\left(\mathrm{H}_{1}\right)-$ a mixture of $2 \mathrm{D}$ hexagonal and micelle cubic $\left(\mathrm{H}_{1}+\mathrm{I}\right)-$ micelle cubic $(\mathrm{I})$ - micelle $\left(\mathrm{L}_{1}\right)$ phases. The phase behaviors, specifically at low temperatures, and the first phase diagram of the $\mathrm{ZnX}-\mathrm{C}_{12} \mathrm{EO}_{10}$ system was investigated using polarized optical microscopy (POM), X-ray diffraction (XRD), differential scanning calorimetry (DSC), Fourier transform infrared (FTIR), and Raman techniques and conductivity measurements.
\end{abstract}

\section{Introduction}

Many surfactant molecules, in an aqueous media, form micelles and lyotropic liquid crystalline (LLC) mesophases depending on the surfactant concentration. ${ }^{1-5}$ Moreover, the aqueous media can be replaced by other solvents, such as organics ${ }^{6}$ or organic ionic liquids, ${ }^{7}$ but the best known solvent to date in the assembly process is water. In previous work, we have introduced an LLC mesophase that contains only a transition metal nitrate hexahydrate salt and nonionic surfactant. ${ }^{8}$ For instance, the $\mathrm{ZnX}-$ $\mathrm{C}_{12} \mathrm{EO}_{10}\left(\mathrm{ZnX}\right.$ is $\left[\mathrm{Zn}\left(\mathrm{H}_{2} \mathrm{O}\right)_{6}\right]\left(\mathrm{NO}_{3}\right)_{2}$ and $\mathrm{C}_{12} \mathrm{EO}_{10}$ is $\mathrm{C}_{12} \mathrm{H}_{25^{-}}$ $\left(\mathrm{OCH}_{2} \mathrm{CH}_{2}\right)_{10} \mathrm{OH}$ ) mesophase exists up to $70 \mathrm{w} / \mathrm{w} \%$ (weight of salt over total weight percent) $\mathrm{ZnX}$ at room temperature (RT). ${ }^{8}$ The salt content of the mesophase can be further increased by adding a charge surfactant into the media, ${ }^{9}$ where the $\mathrm{ZnX}$ content can be as high as $80 \mathrm{w} / \mathrm{w} \%$ at RT. The metal ion can be $\mathrm{Zn}(\mathrm{II}), \mathrm{Cd}(\mathrm{II}), \mathrm{Ni}(\mathrm{II}), \mathrm{Co}(\mathrm{II}), \mathrm{Mn}(\mathrm{II})$, or La(III), the counteranion can be nitrate, perchlorate, or chloride, and the surfactant molecules can be oligo(ethylene oxides) or pluronics in the salt $-\mathrm{C}_{12} \mathrm{EO}_{10}(\mathrm{~S}-\mathrm{EO})$ mesophases. ${ }^{8,10-12}$ The water molecules

*To whom correspondence should be addressed. Fax: (90) 3122664068 E-mail: dag@fen.bilkent.edu.tr.

(1) Mitchell, D. J.; Tiddy, G. J. T.; Waring, L.; Bostock, T.; McDonald, M. P. J. Chem. Soc., Faraday Trans. I 1983, 79, 975.

(2) Chernik, G. G. Curr. Opin. Colloid Interface Sci. 2000, 4, 381

(3) Kunieda, H.; Umizu, G.; Aramaki, K. J. Phys. Chem. B 2000, 104, 2005.

(4) Wang, C. Q.; Chen, D. R.; Jia, X. L. Sci. Technol. Adv. Mater. 2009, 10, 023001 .

(5) Dong, R.; Hao, J. C. Chem. Rev. 2010, 110, 4978-5022.

(6) Ray, A. J. Am. Chem. Soc. 1969, 91,6511.

(7) (a) Binnemans, K. Chem. Rev. 2005, 105, 4148. (b) Greaves, T. L.; Drummond, C. J. Chem. Soc. Rev. 2008, 37, 1709.

(8) Celik, Ö.; Dag, Ö. Angew. Chem., Int. Ed. 2001, 40, 3800.

(9) Albayrak, C.; Soylu, A. M.; Dag, Ö. Langmuir 2008, 24, 10592

(10) Dag, Ö.; Alayoğlu, S.; Uysal, I. J. Phys. Chem. B 2004, 108, 8439.

(11) Demirörs, A. F.; Eser, B. E.; Dag, Ö. Langmuir 2005, 21, 4156

(12) (a) Selivanova, N. M.; Lobkov, V. S.; Barabanov, V. P.; Salikhov, K. M.;

Haase, W.; Galyametdinov, Y. G. Dokl. Chem. (Engl. Transl.) 2005, 401, 51.

(b) Selivanova, N. M.; Osipova, V. V.; Galyametdinov, Y. G. Russ. J. Phys. Chem. (Engl. Transl.) 2006, 80, 649. (c) Zakharova, L. Y.; Ibragimova, A. R.; Valeeva, F. G.; Kudryavtseva, L. A.; Konovalov, A. I.; Zakharov, A. V.; Selivanova, N. M.; Osipova, V. V.; Strelkov, M. V.; Galyametdinov, Y. G. J. Phys. Chem. C 2007, 111, 13839. (only water source is the transition metal aqua complexes) and/or the counteranions are coordinated to the metal ions in the S-EO mesophases. The metal ions interact with the ethoxy groups of the surfactant molecules through their coordinated water molecules via hydrogen-bonding to form the LLC mesophases. ${ }^{8,10,13}$ However, if the metal ion binds to the ethylene oxide groups of the surfactant molecules, a metal-surfactant complex forms and precipitates as a solid crystalline product. ${ }^{13}$ It is also useful to emphasize some of the distinctions between the water-salt-surfactant (W-S-EO) and the S-EO LLC mesophases. Addition of transition metal salt species to the water-surfactant LLC mesophase at low salt concentrations either slightly decreases or increases the isotropization temperature $\left(T_{\mathrm{i}}\right)$ of the mesophase, depending on the counteranion, but destroys the mesophase at around a $20 \mathrm{w} / \mathrm{w} \%$ salt concentration. However, the salt concentration can be as high as $70 \mathrm{w} / \mathrm{w} \%$, and the $T_{\mathrm{i}}$ has been recorded as high as $120^{\circ} \mathrm{C}$ in the $\mathrm{S}$-EO mesophases. Evaporation of water in the W-S-EO system collapses the mesophase, but the S-EO mesophases are stable for years under ambient conditions and respond to humidity. Further details of these distinctions can be found in our earlier work. ${ }^{8,10,11,13}$ However, the nature of salt-surfactant systems is still not fully understood. Questions such as which component of the mesophase acts as the solvent in the S-EO system; what is the state of the salt in the media; what is the stability of the mesophase at low temperatures; and what is unique about the salt-surfactant mesophase have not been answered yet. The answers to these questions will impact the synthesis of metal containing ordered mesoporous metals, metal oxides, or metal chalcogenites solid powders or films. ${ }^{14,15}$ In this contribution, we investigate the

(13) Dag, Ö.; Samarskaya, O.; Tura, C.; Günay, A.; Çelik, Ö. Langmuir 2003, 19,3671 .

(14) (a) Braun, P. V.; Osenar, P.; Stupp, S. I. Nature 1996, 380, 325. (b) Attard, G. S.; Göltner, C. G.; Corker, J. M.; Henke, S.; Templer, R. H. Angew. Chem., Int. Ed. 1997, 36, 1315. (c) Dag, Ö.; Alayoğlu, S.; Tura, C.; Çelik, Ö. Chem. Mater. 2003, 15, 2711. (d) Yamauchi, Y.; Sugiyama, A.; Morimoto, R.; Takai, A.; Kuroda, K. Angew. Chem., Int. Ed. 2008, 47, 5371.

(15) Attard, G. S.; Glyde, J. C.; Göltner, C. G. Nature 1995, 378, 366. 
(A)

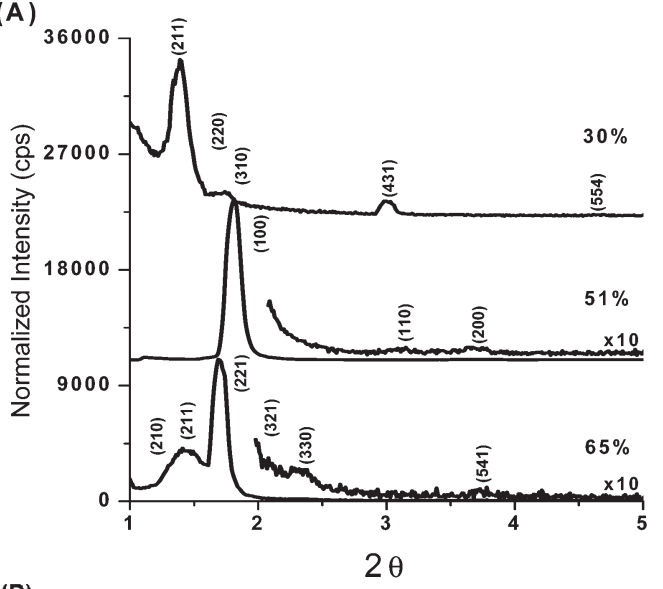

(B)

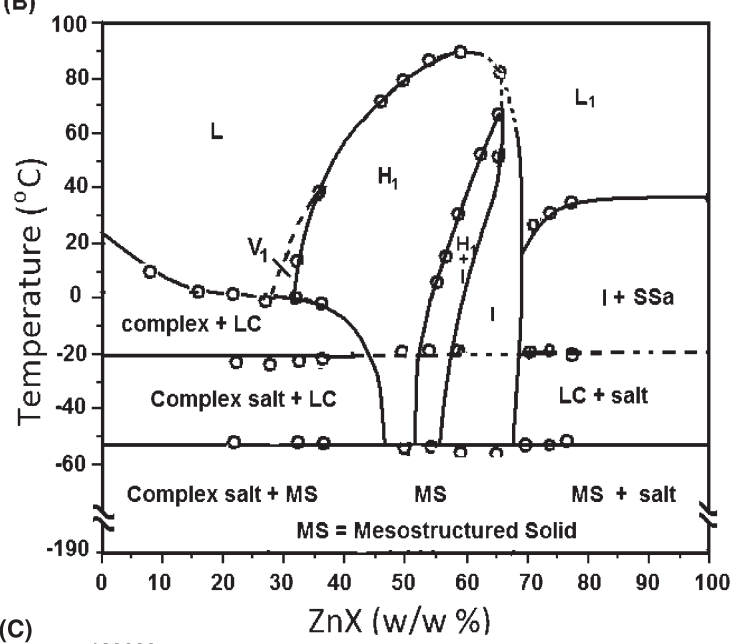

(C)

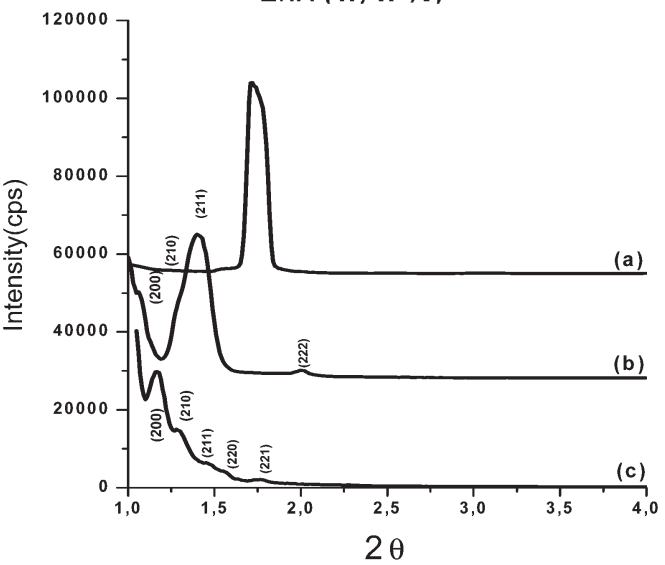

Figure 1. (A) $\mathrm{XRD}$ pattern of $\mathrm{ZnX}-\mathrm{C}_{12} \mathrm{EO}_{10}$ with $\mathrm{ZnX} \mathrm{w} / \mathrm{w} \%$ of 30 (top), 51 (middle two), and 65 (bottom two). (B) Phase diagram of the $\mathrm{ZnX}-\mathrm{C}_{12} \mathrm{EO}_{10}$ system. (C) XRD patterns of a $57.1 \mathrm{w} / \mathrm{w} \% \mathrm{ZnX}, \mathrm{ZnX}-\mathrm{C}_{12} \mathrm{EO}_{10}$ sample (a) at RT and (b, c) below $-20{ }^{\circ} \mathrm{C}$.

$\mathrm{ZnX}-\mathrm{C}_{12} \mathrm{EO}_{10}$ LLC mesophases to bring new insights to the $\mathrm{S}$-EO mesophases. During the investigation we have used a hotcold stage with polarized optical microscopy (POM), X-ray diffraction (XRD), differential scanning calorimetry (DSC), conductivity measurements, Raman, and Fourier transform infrared (FTIR) techniques.

\section{Results and Discussion}

Figure 1A shows the XRD patterns of the samples that have $\mathrm{ZnX} \mathrm{w/w \%} \mathrm{of} \mathrm{30,} \mathrm{51,} \mathrm{and} 65$ from top to bottom at room temperature. The top diffraction lines, in Figure 1A, are obtained from the $30 \mathrm{w} / \mathrm{w} \%$ sample that has a bicontinuous cubic phase. The diffraction lines at $1.39^{\circ}(63.3 \AA), 1.61^{\circ}(54.8 \AA), 1.80^{\circ}(49.0$ $\AA), 3.00^{\circ}(30.3 \AA)$, and $4.66^{\circ}(19.0 \AA), 2 \theta$ can be indexed to $(211)$, (220), (310), (431), and (554) planes, respectively, of the Ia3d space group with a unit cell parameter, $a$, of $155 \AA$ A. At higher $\mathrm{ZnX}$ concentrations (between 36 and $60 \mathrm{w} / \mathrm{w} \%$ ), the mesophase has a 2D hexagonal structure that diffracts three lines at $1.82^{\circ}(48.8 \AA)$, $3.20^{\circ}(27.5 \AA)$, and $3.70^{\circ}(24.3 \AA), 2 \theta$ corresponding to (100), (110), and (200) planes, respectively, of the $P 6 \mathrm{~mm}$ space group (see Figure 1A middle XRD pattern) with a unit cell parameter, $a$, of 56 A. Note also that the POM images, between 36 and $60 \mathrm{w} / \mathrm{w} \%$, display focal conic fan texture, characteristic of the 2D hexagonal mesophase (see latter). The samples display a single XRD line with a dark POM image between the cross polarizers in the micelle cubic mesophase. The $65 \mathrm{w} / \mathrm{w} \% \mathrm{ZnX}-\mathrm{C}_{12} \mathrm{EO}_{10}$ sample has six diffraction lines that can be indexed to (210), (211), (221), (321), (330), and (541) of the Pm3n space group with a unit cell parameter, $a$, of $156 \AA$ (Figure 1A). A complete phase diagram, shown in Figure 1B, was established using POM, DSC, and XRD techniques and Raman spectroscopy. The isotropization temperatures, normal hexagonal $\left(\mathrm{H}_{1}\right)$ to hexagonal/cubic coexisting region $\left(\mathrm{H}_{1}+\mathrm{I}\right)$, and then to cubic mesophase transitions were determined using POM by slowly cooling $\left(1^{\circ} \mathrm{C} / \mathrm{min}\right)$ the samples down to the temperature of liquid nitrogen. Figure $1 \mathrm{C}$ shows the XRD patterns of a $57.1 \mathrm{w} / \mathrm{w} \% \mathrm{ZnX}-\mathrm{C}_{12} \mathrm{EO}_{10}$ sample at $\mathrm{RT}$ and below $-20^{\circ} \mathrm{C}$, showing a $2 \mathrm{D}$ hexagonal to cubic phase transition. Both traces $\mathrm{b}$ and $\mathrm{c}$ in Figure $1 \mathrm{C}$ are recorded below $-20^{\circ} \mathrm{C}$, and the diffraction lines in both traces can be indexed to the same space group $(P m 3 n)$ and unit cell parameters ( $a$ is equal to $152 \AA$ ). It is likely that there is an orientation change during the cooling stage of sample. Two major events were observed in the DSC thermographs (see Supporting Information) of all samples upon cooling, at around -20 and $-52{ }^{\circ} \mathrm{C}$. The former event is related to the leaching out of some surfactant or a salt-surfactant complex (see Supporting Information for discussion), and the latter event is related to a glass transition. Both events appear as horizontal lines in the phase diagram. However, the magnitude of the thermal event at around $-20{ }^{\circ} \mathrm{C}$ gradually decreases with an increasing salt content of the mesophase (see Supporting Information Figure S1).

The transitions from bicontinuous cubic $\left(\mathrm{V}_{1}\right)$ to normal hexagonal $\left(\mathrm{H}_{1}\right)$ then $\mathrm{H}_{1}$ to micelle cubic $(\mathrm{I})$ and then to micelle $\left(\mathrm{L}_{1}\right)$ phase are also common in many LLC systems. ${ }^{1-5}$ However, the $\mathrm{ZnX}-\mathrm{C}_{12} \mathrm{EO}_{10}$ system shows the persistent existence of a liquid crystalline phase down to $-52{ }^{\circ} \mathrm{C}$ and then the presence of an ordered mesostructured solid phase below $-52{ }^{\circ} \mathrm{C}$. The glass transition is likely related to the salt species. It is well-known that hydrated transition metal salts show glass transition depending on the hydration number and the counterion. ${ }^{16}$ The sample becomes a mesostructured glassy salt below $-52{ }^{\circ} \mathrm{C}$, and upon heating it first transforms into the LLC mesophase at around $-52^{\circ} \mathrm{C}$ and then into a liquid at around 10 to $90^{\circ} \mathrm{C}$, depending on the salt content. ${ }^{8}$

We have also recorded the FTIR and Raman spectra of the samples over a broad range of compositions to elucidate the nature of salt and surfactant species. Notice that, at around $36 \mathrm{w} / \mathrm{w} \%$ $\mathrm{ZnX}$ content, in the $\mathrm{ZnX}-\mathrm{C}_{12} \mathrm{EO}_{10}$ sample, major changes are observed in the surfactant signals (LLC formation), but no more changes are observed above $60 \mathrm{w} / \mathrm{w} \%$, where the mesophase is cubic or micelle liquid (Figure 2). We also included a spectrum of the molten $\mathrm{ZnX}$ that melts at around $36.4{ }^{\circ} \mathrm{C}$. The similarity in the nitrate stretching region of the spectra of the molten $\mathrm{ZnX}$ and

(16) (a) Jain, S. K.; Tamamushi, R. Can. J. Chem. 1980, 58, 1697. (b) Angell, C. A.; Sare, E. J. J. Chem. Phys. 1970, 52, 1058. 


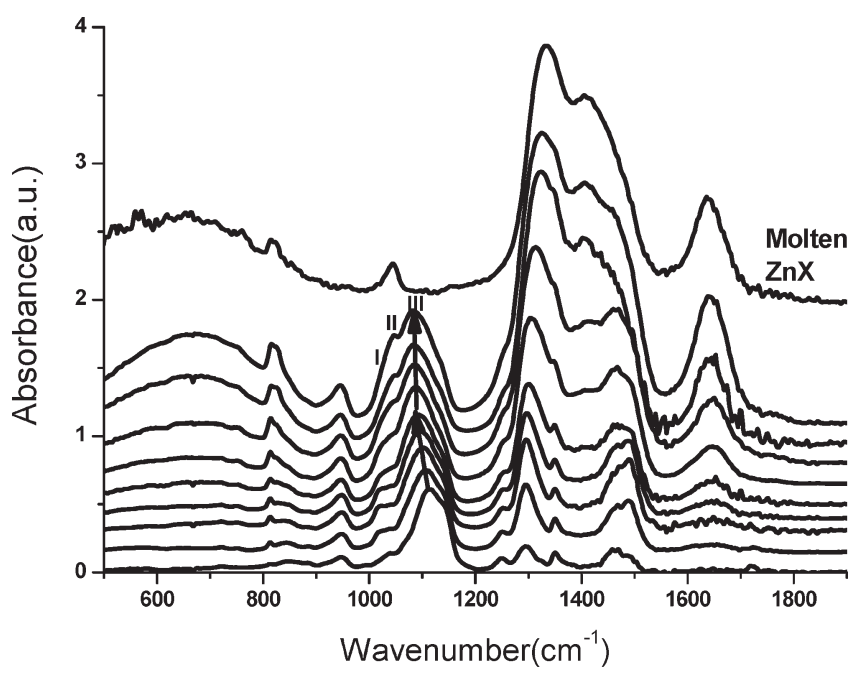

Figure 2. FTIR spectra of $\mathrm{ZnX}-\mathrm{C}_{12} \mathrm{EO}_{10}$ with $\mathrm{ZnX} \mathrm{w} / \mathrm{w} \%$ of (bottom to top) 8.7, 27.5, 36.3, 46.1, 57.1, 65.5, 70.4, and 74.0; the top spectrum is the molten $\mathrm{ZnX}$.

the LLC samples, above $60 \mathrm{w} / \mathrm{w} \% \mathrm{ZnX}-\mathrm{C}_{12} \mathrm{EO}_{10}$, is quite striking. $\mathrm{Up}$ to $60 \mathrm{w} / \mathrm{w} \% \mathrm{ZnX}-\mathrm{C}_{12} \mathrm{EO}_{10}$, the nitrate region shows mainly coordinated nitrate signals ${ }^{13}$ at 1300 and $1480 \mathrm{~cm}^{-1}$. Above $57.1 \mathrm{w} / \mathrm{w} \%$, the free nitrate signal, at $1410 \mathrm{~cm}^{-1}$, appears and dominates the spectra, as in the molten phase of the pure salt. Symmetric stretching modes of the nitrate species (peaks I and II in Figure 2) also follow the same trend, where peak II dominates this region above $57.1 \mathrm{w} / \mathrm{w} \%$. The $v$-CO stretching mode (peak III in Figure 2) of the surfactant (EO units) steadily shifts from 1115 to $1090 \mathrm{~cm}^{-1}$ with an increasing $\mathrm{ZnX}$ content up to $57.1 \mathrm{w} / \mathrm{w}$ $\%$, and then the shift almost stops above this ratio, indicating that the EO domain of the mesophase is saturated with the salt species. Above $60 \mathrm{w} / \mathrm{w} \%$, the sample undergoes a phase change from $2 \mathrm{D}$ hexagonal to micelle cubic phase. Above $70 \mathrm{w} / \mathrm{w} \%$, the mesophase undergoes another phase change into a micelle liquid phase. The surface charge of the molten phase, in the molten-surfactant interface, cannot be balanced above $70 \mathrm{w} / \mathrm{w} \%$ even in the cubic mesophase. However, the addition of a charged surfactant into the media stabilizes the columnar phase up to $80 \mathrm{w} / \mathrm{w} \% \mathrm{ZnX}-$ $\mathrm{C}_{12} \mathrm{EO}_{10} \cdot{ }^{17}$ Based on our observations, we believe that the salt species are in the molten phase in the hydrophilic domains of the mesophase, acting as the solvent (ionic liquid) of the media.

Keeping this idea in mind, we have carried out the following experiments to further prove the concept. Since the $\mathrm{ZnX}$ species are in a molten phase and their freezing point is depressed, we have recorded the POM images (between $-190{ }^{\circ} \mathrm{C}$ and $\mathrm{RT}$ ), Raman spectra between RT and $-120{ }^{\circ} \mathrm{C}$, XRD patterns below $T_{\mathrm{g}}$, and DSC thermographs (between RT and $-70{ }^{\circ} \mathrm{C}$ ) of the samples. Figure 3 shows a series of POM images of $48.7 \mathrm{w} / \mathrm{w} \%$ $\mathrm{ZnX}-\mathrm{C}_{12} \mathrm{EO}_{10}$ at $25,-9.7,-20.1,-101.4$, and $-163{ }^{\circ} \mathrm{C}$ obtained while cooling and heating the sample back to $0^{\circ} \mathrm{C}$. Notice that the POM images display a focal conic fan texture (characteristic for a 2D hexagonal phase) at all temperatures. However, below $-100{ }^{\circ} \mathrm{C}$ (depending on the sample thickness), the sample cracks like a solid film sample. Heating these samples recovers the crack pattern by first healing the crack regions, and then at around $-30{ }^{\circ} \mathrm{C}$ a complete recovery was observed. Notice also that the focal conic fan texture remains throughout the cooling process, down to liquid nitrogen temperatures. There is no separation of salt and surfactant species at all temperatures with this composition.

(17) Albayrak, C.; Soylu, A. M.; Dag, Ö. J. Colloid Interface Sci. 2010, 341, 109.

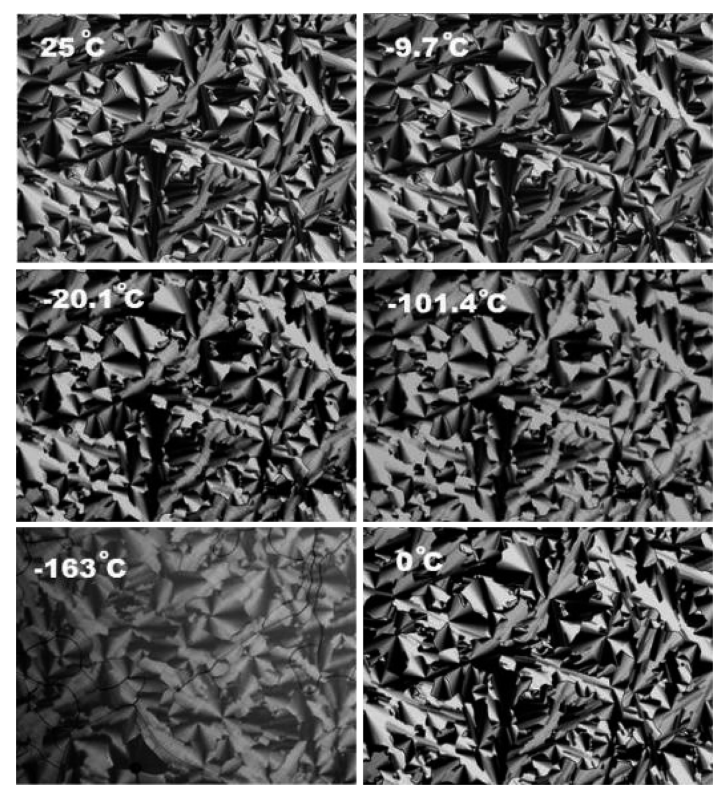

Figure 3. POM images of $48.7 \mathrm{w} / \mathrm{w} \% \mathrm{ZnX}-\mathrm{C}_{12} \mathrm{EO}_{10}$ at 25 , $-9.7,-20.1,-101.4$, and $-163^{\circ} \mathrm{C}$ during cooling and after heating to $0{ }^{\circ} \mathrm{C}$.

These observations indicate that the salt-surfactant LLC mesophase undergoes a phase change to a solid mesostructure. To the best of our knowledge, this is the first time the mesostructured solid to LLC transition has been observed in a lyotropic liquid crystalline system.

$\mathrm{ZnX}-\mathrm{C}_{12} \mathrm{EO}_{10}$ forms micelle cubic LLC mesophases above 60 $\mathrm{w} / \mathrm{w} \%$ at RT. However, the cubic phase also exists at lower $\mathrm{ZnX}-\mathrm{C}_{12} \mathrm{EO}_{10} \mathrm{w} / \mathrm{w} \%$ and lower temperatures (see Figure $1 \mathrm{C}$ ). Supporting Information Figure S2 shows the POM images of the $58.8 \mathrm{w} / \mathrm{w} \%$ sample recorded at $33,20.1,1.5$, and $-21.4{ }^{\circ} \mathrm{C}$ while cooling and after heating back to 17 and $40{ }^{\circ} \mathrm{C}$ (this sample was also cooled down to liquid nitrogen temperatures before heating). Notice that the mixture has hexagonal LLC mesophase at around $33{ }^{\circ} \mathrm{C}$ and starts transforming into a cubic mesophase at around $28^{\circ} \mathrm{C}$. Between 28 and $-20^{\circ} \mathrm{C}$, both the $\mathrm{H}_{1}$ and I phase coexist. Further cooling the sample makes it crack as in the hexagonal mesostructured solid (not shown). Heating this sample back to $40{ }^{\circ} \mathrm{C}$ first heals the cracks, and then the sample undergoes a transformation to a cubic LLC mesophase, then changes to a mixture of $\mathrm{H}_{1}$ and $\mathrm{I}$, and then finally changes to $\mathrm{H}_{1}$ at around $30{ }^{\circ} \mathrm{C}$ (see Figure $1 \mathrm{~B}$ for other compositions). Moreover, heating the sample back to $40{ }^{\circ} \mathrm{C}$ reforms the $\mathrm{H} 1$ mesophase, restoring the exact focal conic fan texture and the defect pattern of the sample before cooling (compare first and last images in Supporting Information Figure S2). This observation indicates that the defect pattern in the hexagonal mesophase is kept the same in the cubic mesophase and cubic mesostructured $\mathrm{ZnX}-\mathrm{C}_{12} \mathrm{EO}_{10}$. Note also that the defect pattern never forms exactly the same if the samples are heated to melting and then cooled back to the LLC mesophase (the same is true if there is a phase separation during cooling). This behavior clearly shows that the mesophase and mesostructure are preserved throughout the cooling down to liquid nitrogen temperatures and heating of the samples.

The Raman spectra of some key samples were also recorded from RT to $-120^{\circ} \mathrm{C}$ to further enlighten the phase behavior of the $\mathrm{ZnX}-\mathrm{C}_{12} \mathrm{EO}_{10}$ LLC mesophase (Figure S3 in the Supporting Information). Note that the nitrate species are observed at 1030 , 1047 , and $1057 \mathrm{~cm}^{-1}$, corresponding to a coordinated nitrate, free nitrate, and nitrate in $\mathrm{ZnX}$, respectively. ${ }^{13}$ The coordinated 
nitrate signal completely disappears at around $-30{ }^{\circ} \mathrm{C}$, and no more changes are observed down to $-120^{\circ} \mathrm{C}$ (likely even at lower temperatures). The only peak observed below $-30{ }^{\circ} \mathrm{C}$ is due to free nitrate ions. It means that the salt species freeze as in the liquid phase. Up to $70 \mathrm{w} / \mathrm{w} \%$, no peak, due to $\mathrm{ZnX}$ crystals, was observed in the Raman spectra at any temperature. However, above $70 \mathrm{w} / \mathrm{w} \%$, a new relatively sharp peak appears at $1057 \mathrm{~cm}^{-1}$ below $-10^{\circ} \mathrm{C}$, due to salt crystals (see Supporting Information Figure S3). Note also that the melting curve above $70 \mathrm{w} / \mathrm{w} \%$ in the phase diagram is determined while heating the samples, because the salt in this media shows super cooling (while the melting occurs at around $20-30{ }^{\circ} \mathrm{C}$, the crystallization is observed below $-10{ }^{\circ} \mathrm{C}$ ).

To gain further insight into the nature of the salt species in the mesophase, we have also recorded the conductivity of a series of samples using an AC impedance spectroscopy method. The conductivity values change between $7.0 \times 10^{-5}$ and $2.1 \times 10^{-3} \mathrm{~S} \mathrm{~cm}^{-1}$ depending on the salt content of the mesophase. The conductivities recorded for the $\mathrm{ZnX}-\mathrm{C}_{12} \mathrm{EO}_{10}$ mesophase at $\mathrm{RT}$ get closer to the molten phase of $\mathrm{ZnX}$ at higher salt concentrations. ${ }^{16}$

\section{Conclusion}

In summary, the spectral, structural, thermal, and conductivity properties of the salt-surfactant LLC mesophases show that the salt species are in the molten phase and act as a solvent in the $\mathrm{ZnX}-\mathrm{C}_{12} \mathrm{EO}_{10}$ systems. The phase diagram looks like a typical phase diagram of a water-surfactant system that shows $\mathrm{V}_{1}, \mathrm{H}_{1}, \mathrm{I}$, and $\mathrm{L}_{1}$ phases with increasing the solvent of the media. However, the $\mathrm{ZnX}-\mathrm{C}_{12} \mathrm{EO}_{10}$ mesophase displays an unusual phase behavior at low temperatures when compared to all known LLC systems; it shows a glass transition at around $-52^{\circ} \mathrm{C}$ and freezes into a transparent mesostructured solid upon cooling below $-52{ }^{\circ} \mathrm{C}$. The mesostructure is stable even at liquid nitrogen temperatures, but the film samples crack upon cooling below $-100{ }^{\circ} \mathrm{C}$. The salt-surfactant systems may be unique for low temperature applications and may be used to produce new advanced materials. We believe this contribution will bring some new insight into the salt-surfactant mesophases, but uncovers many new questions that are worth investigating.

\section{Experimental Section}

Samples that contain $0.0-77 \mathrm{w} / \mathrm{w} \%$ (weight of salt over total weight percent) were prepared using the required ( 0.0 to $3.326 \mathrm{~g}$ ) amounts of $\mathrm{ZnX}\left(\left[\mathrm{Zn}\left(\mathrm{H}_{2} \mathrm{O}\right)_{6}\left(\mathrm{NO}_{3}\right)_{2}\right)\right.$ and $1.0 \mathrm{~g}$ of $\mathrm{C}_{12} \mathrm{EO}_{10}$. The mixtures were put into sealed glass vials and constantly shaken at temperatures just above the melting point of the composition for 1 day. The samples that have melting points above $80^{\circ} \mathrm{C}$ were homogenized above their melting points for $12 \mathrm{~h}$ and then kept at $60{ }^{\circ} \mathrm{C}$ for another $12 \mathrm{~h}$ to avoid decomposition of the nitrate species.

The XRD patterns were recorded on a Rigaku Miniflex diffractometer using a high power $\mathrm{Cu}-\mathrm{K} \alpha$ source operating at $30 \mathrm{kV} / 15 \mathrm{~mA}$. The RT measurements were carried out by spreading the samples on glass slides. The low temperature measurements were performed by cooling the samples in a homemade sample holder. The POM images were obtained in transmittance mode on a ZEISS Axio Scope A1 polarizing optical microscope with a Linkam LTS350 temperature controlling stage attached to the microscope. Temperature control was done using a Linkam T95-LinkPad temperature programmer attached to the stage. The FTIR spectra were recorded using a Bruker Tensor 27 model FTIR spectrometer. A Digi Tect TM DLATGS detector was used with a resolution of $4.0 \mathrm{~cm}^{-1}$ in the $400-4000 \mathrm{~cm}^{-1}$ range. The spectra were recorded by spreading the samples on silicon wafers. The micro-Raman spectra were recorded on a LabRam confocal Raman microscope with a $300 \mathrm{~mm}$ focal length. The spectrometer is equipped with a Ventus LP $53250 \mathrm{~mW}$, diodepumped solid-state laser operated at $20 \mathrm{~mW}$, with a polarization ratio of 100:1, a wavelength of $532.1 \mathrm{~nm}$, and a $1024 \times 256$ element CCD camera. The signal collected was transmitted via a fiber optic cable into a spectrometer with a $600 \mathrm{~g} / \mathrm{mm}$ grating. The Raman spectra were collected by manually placing the probe tip near the desired point of the sample on a silicon wafer, located on the same heating-cooling stage used for the POM imaging. The DSC measurements were carried out using a Perkin-Elmer Diamond differential scanning calorimeter. Both heating and cooling scans were recorded between -65 and $80{ }^{\circ} \mathrm{C}$ using a rate of $2{ }^{\circ} \mathrm{C} / \mathrm{min}$. AC impedance conductivity measurements were carried out using a Gamry G750 potentiostat/galvanostat by sandwiching the samples between two platinum plates with a cell constant of $6.4 \times 10^{-2} \mathrm{~cm}$.

Acknowledgment. This work was supported by the Scientific and Technical Research Council of Turkey (TÜBITAK) in the framework of the projects 109T042 and Turkish Academy of Science.

Supporting Information Available: DSC thermographs, POM images, and Raman spectra. This material is available free of charge via the Internet at http://pubs.acs.org. 